Vol. 2, No. 1, 2021

Igor Kuzio, Mariia Sokil

Lviv Polytechnic National University

12, Bandery Str., Lviv, 79000, Ukraine

(C) Kuzio I., Sokil M., 2021

https://doi.org/10.23939/tt2021.01.060

\title{
THE INFLUENCE OF DEGREE OF LOADING AND LOAD PLACING ON STEERABILITY OF VEHICLES
}

Summary. The methodology of research of the influence of the degree of loading, kinematic parameters of movement, and nonlinear power characteristics of elastic elements and shockabsorbers of the suspension system on their steerability on curved sections of the road is developed. The research is based on the equation of kinetostatics of the system of sprung-unsprung part and differential equations that relate the motion of the sprung part of vehicles. Concerning the last, they take into account both loading of a vehicle and nonlinear-elastic characteristics of shock-absorbers. For the case when elastic characteristics of shock-absorbers are described by degree or close to it dependence, the fluctuation of sprung part is described analytically. Their peculiarity is that the frequency and therefore dynamic force of wheels pressure on the bearing surface (road) depends on the amplitude. It is the last value and characteristics of the road surface that determine the main parameters of steerability and stability of the movement of wheeled vehicles along curved sections of the road. Taken together, the mentioned above allowed to obtain the dependence of the critical value of the dynamic angle of rotation of the steered wheels, as a function of the amplitude of longitudinalangular oscillations, kinematic motion parameters, and the level of loading of a vehicle. It is established:

- fluctuation of the sprung part significantly reduce the value of the limiting angle of rotation of the steered wheels along the curved sections of the road;

- for the period of acceleration of the vehicle and the closer location of the center of gravity of the cargo transported to the tailgate, the limit value of the dynamic angle of rotation of the steered wheels is less;

- the suspension system with the progressive law of change of regenerative force of elastic shock-absorbers in a wider range of change fluctuations amplitude of the suspended part satisfies ergonomic conditions of transportation.

The obtained calculated dependencies can simultaneously be basic during the modernization of existing or the creation of new suspension systems in order to improve the main operation characteristics of wheeled vehicles.

Key words: vehicles, steerability, stability of motion, suspension system, sprung part, critical speed, oscillations, load.

\section{INTRODUCTION}

Steerability and stability of motion of wheeled vehicles characterize to some extent the ability to change the direction of safe motion of a vehicle and keep it due to a driver's action on a steering wheel [1]. The main value that determines these characteristics (steerability, stability of motion, passability) in the end, is the loading on a tire and the forces of its interaction with the road pavement, etc. In the case of steady motion along a road without irregularities, the specified values are constant and therefore the limit value of the steering wheel angle or the critical speed of steady motion along the curved section is constant. 
However, during unsteady motion (accelerated or decelerated) with various degrees of loading and the motion of a vehicle along the road with irregularities, the dynamic pressure force on the tires is variable and therefore changes the basic operational characteristics. The load component on the tires which is due to the dynamics of the sprung part depends on the degree of loading of a vehicle, its distribution in the body, and the force characteristics of the suspension system.

Thus, the issue of assessment of the basic operational characteristics of a vehicle should be considered comprehensively, taking into account the main external and internal factors. Such questions are the subject of this research. Also, when considering the influence of the dynamics of the sprung mass of a wheeled vehicle on the limit values of the angle of steerability and the speed of stable motion, it is assumed that the elastic force characteristics of the suspension system are described by a nonlinear ratio [1-3], which more accurately reflects the real picture of the process of the sprung part.

\section{RESEARCH STATEMENT}

There are various approaches to solve the task partially, in particular, experimental, analog, or mathematical modeling of the process, etc. However, experimental or bench studies $[4,5]$ which are related to the separate influence of certain force factors on the dynamics of the sprung mass (SM) with a nonlinear force characteristic of the suspension system (SS), provided the purity of the experiment, can not answer the question of their compatible impact. This is because there is no superposition principle for nonlinear systems. Besides, experimental studies require significant material and time resources. A similar drawback is characteristic of the numerical simulation of mathematical models of the dynamic process of motion of a wheeled vehicle as a mechanical system of sprung - unsprung part $[5,6]$.

The latter are usually ordinary nonlinear differential equations. In [7-10], using their approximate analytical integration, a number of features of the dynamic process of a wheeled vehicle in comparison with linear models are shown. This primarily concerns the dependence of the frequency of natural oscillations on the amplitude and hence the influence of the latter on the ergonomic operating conditions of a wheeled vehicle, especially the transportation of goods. It is not possible to establish their generalized features on the basis of experimental research or numerical simulation of the corresponding mathematical models. Therefore, the issues related to the peculiarities of the transportation of goods on a wheeled vehicle by physical calculation models that take into account the actual properties of the suspension system are not only of theoretical but also practical value.

\section{THE MAIN MATERIAL}

For a flat model of a wheeled vehicle (see Fig. 1) which moves uniformly accelerated (decelerated) with acceleration (deceleration) $w$ and has at this time the speed $V$, it is necessary to determine the influence of the mass of the object of transportation $(Q)$, its location $(\Delta)$ on the sprung part relative to its mass center of the magnitude of acceleration (deceleration) on steerability.

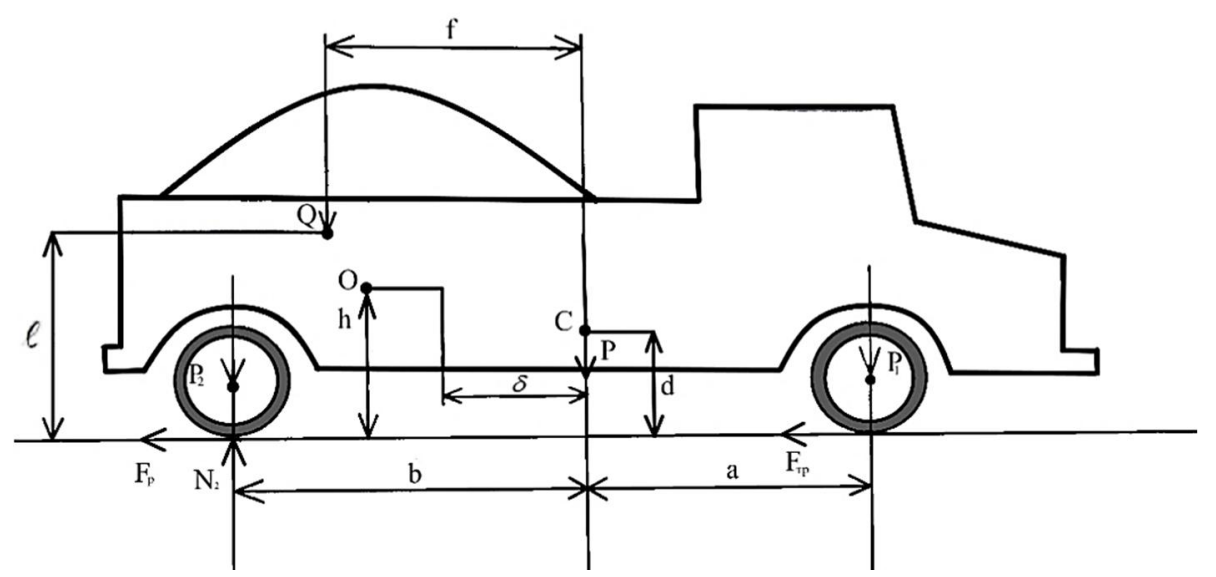

Fig. 1. Calculation model and distribution of external forces of a wheeled vehicle 
For the specified calculation model, let's consider:

- the center of mass of the sprung mass (without load) is at point $\mathrm{O}$ and is determined by the parameters;

- $a, b$ - the distance of the center of mass of the sprung part without any load to the front or rear axles respectively;

$-l, f$-parameters that determine the position of the center of mass of the transported load on the sprung part;

$-h, \delta$ - parameters that determine the position of the center of mass of the sprung part with the load relative to the center of this part without the load;

- $P ; P_{1}, P_{2}$ - the sprung mass of front and rear axles respectively;

- $N_{1}, N_{2}$ - pressure forces of steered and rear wheels on the road surface;

- the suspension system is characterized by elastic forces $F_{\text {iпр }}$ and resistance forces $R_{\text {ion }}$ which are described by the dependences [8] $\mathrm{F}_{i \text { in }}=c_{i} \Delta_{\mathrm{i}}{ }^{\nu+1}, \mathrm{R}_{\text {ion }}=\alpha_{i} \dot{\Delta}_{i}{ }^{s+1}$, where $c_{i}, \alpha_{i}, s$, are constant values, $\Delta_{i}$ and $\dot{\Delta}_{i}$ - the deformation of the elastic elements of the suspension and the speed of the shock absorbers respectively ( $i=1-$ for the front suspension and $i=2-$ for rear suspension);

- $v$ - a parameter that characterizes the deviation of the elastic characteristics of the shock absorbers from the linear law;

- deformation of tires in the process of collision of a wheeled vehicle on the irregularity is a small value in comparison with the deformation of elastic shock absorbers and it will be neglected when solving the problem;

- the maximum values of the resistance forces of the shock absorbers are clearly less than the maximum values of the elastic forces of the suspension;

- irregularities of the road cause small relative oscillations of the sprung mass around the transverse axis which passes through the center of mass of the sprung part with the load.

In this case, its relative position is uniquely determined by the angle of rotation $\varphi(t)$ of the sprung part around the horizontal axis which passes through the center of mass of the sprung part with the load (point $\mathrm{O}$ ) and is perpendicular to the vector of the transfer speed. The angle of steerability of a vehicle is the angle between a plane of steered wheels and the speed of a vehicle [13]. The location of the specified point is determined by the values of the mass of the transported cargo and the sprung part:

$$
\delta=\frac{Q f}{P+Q}, \quad h=\frac{Q l+P d}{P+Q} .
$$

The influence of road irregularities on the oscillations of the sprung part can be the subject of separate research.

As noted above, the limit value of the dynamic angle of steerability is largely determined by the type of the road surface and the value of the pressure force of the steered wheels of the sprung - unsprung mass on the road surface which are equal in magnitude to the dynamic response $N_{l}$. The latter is determined not only by external active forces (mass forces) but also by the forces of inertia of portable motion and the law of relative motion of the sprung mass with the load. If the forces of inertia of the portable motion of the vehicle parts are determined by their masses and the acceleration of the portable motion of a vehicle, i.e. acceleration of portable motion $w$, then to determine the forces of inertia of the relative motion it is necessary to determine the law of oscillations of the sprung mass with the load.

\subsection{The influence of the relative position of the load being transported on the oscillations of} the sprung part of a wheeled vehicle.

The oscillations of the sprung part play a dominant role in determining such dynamic operational characteristics as stability of motion along curved sections of the path, passability, smoothness, steerability. If vertical and transverse-angular oscillations play a dominant role in estimating the stability of motion along curvilinear sections of the path, passability, and smoothness [8-10], then vertical and longitudinal- 
angular oscillations play a dominant role for steerability. Such questions for the case of steady motion by the linear characteristics of the suspension system were partially considered in [11] and for nonlinear - in $[12,13]$.

Therefore, the dynamics of the relative motion of the sprung part with the load being transported in case of the unsteady motion and nonlinear characteristics of the resistance force of the shock absorbers and elastic forces will be described below. The basis for solving this problem will be the differential equation of the relative motion of this part. The forces acting on it and its inertia forces are presented in Fig. 2 .

Thus, the differential equation of longitudinal-angular oscillations of the sprung mass takes the following form:

$$
I_{o} \ddot{\phi}=-(a+\delta)\left(F_{1 n p .}+R_{1 o n .}\right)-(b-\delta)\left(F_{2 n p .}+R_{2 o n .}\right)+M_{O}^{\mathrm{e} . \Phi},
$$

where $\varphi(t)$ - the angle of rotation of the sprung part around the horizontal axis passing through the center of mass of the sprung part with the load and perpendicular to the vector of transfer speed, $I_{o}$ - the moment of inertia of the sprung mass with the load relative to the axis, $\mathrm{M}_{o}^{e . \Phi}-$ the moment of inertia force of the portable motion of the sprung mass with the load relative to the same axis.



Fig. 2. Calculation scheme for the dynamics of the relative motion of the sprung part with the load (for the unsteady motion of a vehicle)

The moment of inertia $I_{O}$ is found according to the Huygens-Steiner theorem [14]:

$$
I_{O}=I_{C}+\frac{P}{g}\left(\delta^{2}+(h-d)^{2}+\frac{Q}{g}\left((f-\delta)^{2}+(l-h)^{2}\right),\right.
$$

where $I_{C}$ - the moment of inertia of the sprung part without load, which is transported relative to the axis passing through its center of mass and parallel to the above axis.

Regarding the deformations of the elastic elements of the suspension system and their speed in any position of the sprung mass with the load, they are determined by the dependences $\Delta_{1}=(a+\delta) \varphi(t)-\Delta_{\text {ст. }}, \dot{\Delta}_{1}=(a+\delta) \dot{\varphi}(t), \Delta_{2}=(d-\delta) \varphi(t), \dot{\Delta}_{1}=(b-\delta) \dot{\varphi}(t)+\Delta_{c \text { т. }}, \Delta_{c \text { с. }}$ - the static deformation of the elastic elements under the action of mass of the sprung part and the transported load. The latter is determined by the following ratios:

$$
\begin{aligned}
& c_{1}\left[(a+\delta) \phi_{0}-\Delta_{c \text { т. }}\right]^{v+1}+c_{2}\left[(b-\delta) \phi_{0}+\Delta_{c \text { т. }}\right]^{v+1}=P+Q, \\
& c_{1}\left[(a+\delta) \phi_{0}-\Delta_{c \text {. . }}\right]^{v+1}(a+\delta)=c_{2}\left[(b-\delta) \phi_{0}+\Delta_{c \text { T. }}\right]^{v+1}(b-\delta),
\end{aligned}
$$

where $\varphi_{0}$ - the angle of inclination of the sprung part with the load to the horizon and below, for simplicity we assume that $\varphi_{0}=0$.

The above allows us with precision to the values of the highest order of magnitude to present the differential equation (2) with respect to the position of relative equilibrium in the form:

$$
I_{o} \ddot{\phi}+\left(c_{1}(a+\delta)^{v+2}+c_{2}(b-\delta)^{v+2}\right) \phi^{v+1}=(v+1) \Delta_{\text {cт. }}\left(c_{1}(a+\delta)^{v+1}-c_{2}(b-\delta)^{v+1}\right) \phi^{v}-
$$




$$
-\left[\alpha_{1}(a+\delta)^{s+2}+\alpha_{2}(b-\delta)^{s+2}\right] \dot{\phi}^{s+1} .
$$

The magnitude of the moment of force of inertia of the portable motion of the sprung part with the load $\mathrm{M}_{o}^{e . \Phi}$, according to the definition [14], is equal to the moment of the main vector of forces of inertia $\mathrm{R}^{e . \Phi}=((P+Q) / g) w$ relative to point $\mathrm{O}$ and therefore equals to zero.

Let us briefly dwell on the solution of the differential equation (5). It is not possible to construct an exact analytical solution. However, the above limitations on the system, more precisely on the characteristics of damper devices, allow using the general ideas of perturbation methods adapted in [15] for the given type of equations. The efficiency of their use largely depends on the possibility of constructing a solution of the corresponding 'non-perturbation' analogue, i.e. the equation:

$$
I_{o} \ddot{\phi}+\left(c_{1}(a+\delta)^{v+2}+c_{2}(b-\delta)^{v+2}\right) \phi^{v+1}=0 .
$$

Its peculiarities are as follows:

firstly, it, like the equation (5), describes the oscillatory process of the sprung part, and therefore the second term, the main part of the moment of elastic forces relative to the center of mass of the specified part with the load, must be an odd function $\varphi$. The specified condition will be true in the case when the parameter $v$ takes values that satisfy the ratio $v+1=(2 m+1) /(2 n+1)(m, n=0,1,2, \ldots)$.

secondly, by performing the above, its periodic solution is expressed through periodic Atebfunctions $[16,17]$ in the form $[12,13]$ :

$$
\phi_{0}(t)=a_{\phi} c a(v+1,1, \psi),
$$

where $a_{\varphi}, \omega\left(a_{\varphi}\right)=\sqrt{\left(c_{1}(a+\delta)^{v+2}+c_{2}(b-\delta)^{v+2}\right)(v+2) /\left(2 I_{0}\right)} a_{\varphi}^{\frac{v}{2}}-$ the amplitude and frequency of natural longitudinal - angular oscillations of the sprung mass with the load, $\omega\left(a_{\varphi}\right) t+\theta$ - the phase of oscillations of the sprung part; $\theta$ - the initial phase;

thirdly, if for the non-perturbation equation the oscillation parameters of the sprung mass are constant and are determined from the initial conditions, then for the perturbation equation they change in time and the laws of their change are determined by the law of change of the right part of the differential equation (5);

fourthly, in the value of the parameters $v=0, \mathrm{~s}=0$ the mathematical model of the dynamics of the sprung part is linear and the natural frequency does not depend on the amplitude;

fifthly, by selecting the parameters $c_{i}$ and $v$ the elastic force of a wide range of suspension systems from elastic cylinders [18] to the usual spring elements of the suspension system which are inclined at a certain angle to the vertical can be described.

The above dependence for the frequency of natural longitudinal oscillations of the sprung mass can be replaced by a more convenient one. If we take into account that the parameters of 'stiffness' of the suspension system $c_{1}, c_{2}$ related by the ratio $c_{2}=\kappa c_{1}(\kappa-$ a known constant which indicates the relationship of stiffness of the front and rear shock absorbers), it is more appropriate to use the concept of static deformation of elastic shock absorbers $-\Delta_{\text {ст. }}$. In this case $\mathrm{c}_{1}=(P+Q) /\left((1+\kappa) \Delta_{\text {ст. }}{ }^{v+1}\right)$, the natural frequency takes the following value:

$$
\omega\left(a_{\phi}\right)=\sqrt{(P+Q)(v+2)\left[(a+\delta)^{v+2}+\kappa(b-\delta)^{v+2}\right] /\left(2(1+\kappa) I_{0} \Delta_{\text {ст. }}^{v+1}\right)} a_{\phi}^{\frac{v}{2}} .
$$

Below in Fig. 3, the dependence of the natural oscillation frequency $f=\frac{\omega\left(a_{\varphi}\right)}{2 \Pi}$ in hertz on the parameters of the system is presented for different values of the parameters of the sprung part with the load, where $\Pi_{\text {is }}$ the half-life of the used periodic Ateb functions, i.e. $\Pi=\sqrt{\pi} \Gamma(1 /(v+2)) \Gamma^{-1}(1 / 2+1 /(v+2)), \Gamma(\ldots)-$ the gamma function of the corresponding argument. 


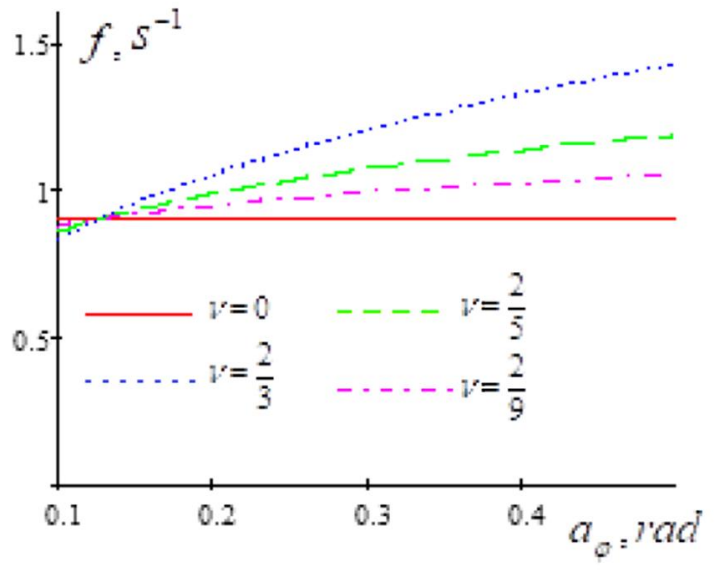

a) $\delta=2 m, \Delta_{\text {ст }}=0.3 m$

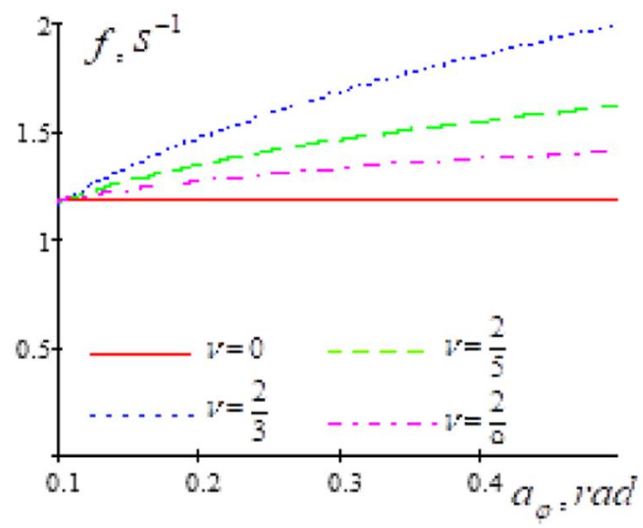

c) $\delta=1.5 m, \Delta_{\text {ст }}=0.25 m$

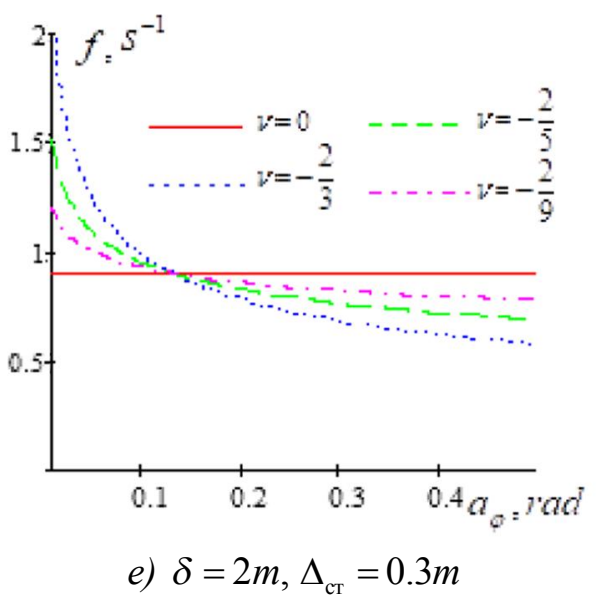

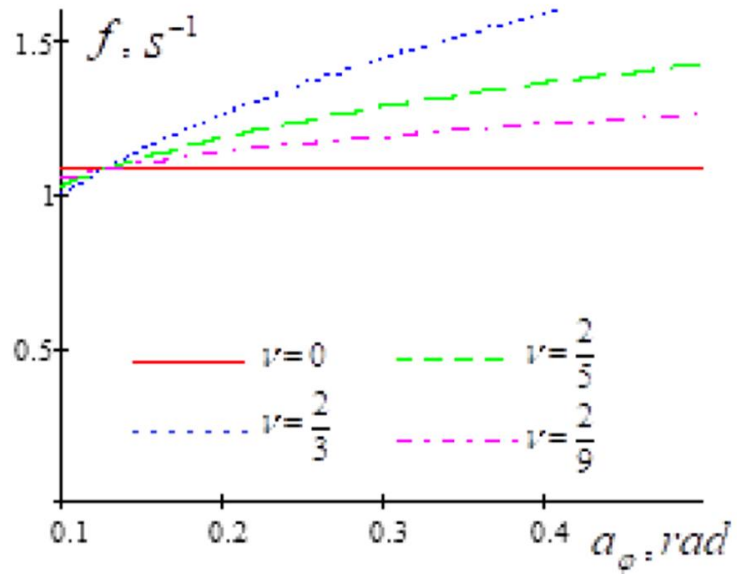

b) $\delta=1.5 m, \Delta_{\text {ст }}=0.3 m$



d) $\delta=2 m, \Delta_{\text {ст }}=0.25 m$



Fig.3. Dependence of the frequency $f$ of oscillations of the sprung part on the amplitude at different values of the parameter vand the location of the load at $a=2 \mathrm{~m}, b=3 \mathrm{~m}, c=1,8 \mathrm{~m}, P=10^{5} \mathrm{~N}, Q=4 \times 10^{5} \mathrm{~N}$

The presented graphical dependences show that for the suspension system with the progressive law of change of elastic force (Fig. $3 a-d$ ), the natural frequency is higher (increasing) for:

a) larger values of the amplitude of longitudinal-angular oscillations of the sprung part;

b) location of the center of mass of the load transported at a greater distance from the rear side;

c) suspension systems with a larger amount of static deformation. 
As for the suspension system with the regressive law of change of elastic force (Fig. 3 e,f), the natural frequency is lower for larger values of amplitude.

The results concerning the dependence of the frequency of the considered natural oscillations on the magnitude of static deformation are of some practical interest. They are presented in fig.4 for different values of the parameters of the system of load-sprung part. At the same time, the obtained graphical dependencies can be the basis for choosing the elastic characteristics of the forces of the suspension system.



a) $\delta=1.5 m, a_{\varphi}=0.3 \mathrm{rad}$

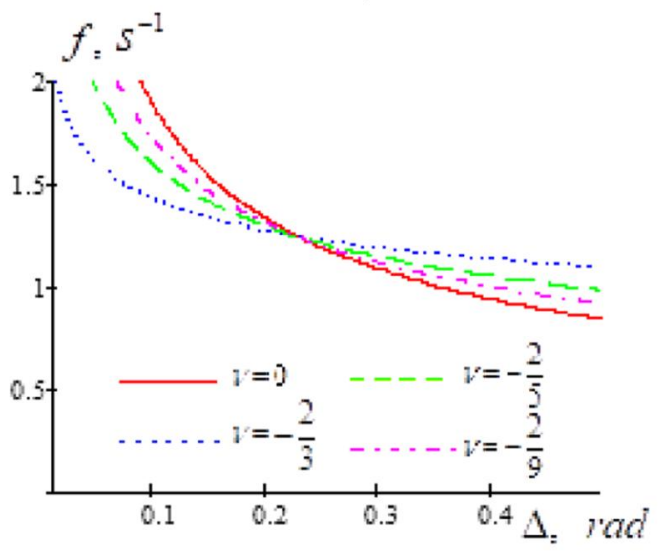

c) $\delta=1.5 m, a_{\varphi}=0.1 \mathrm{rad}$

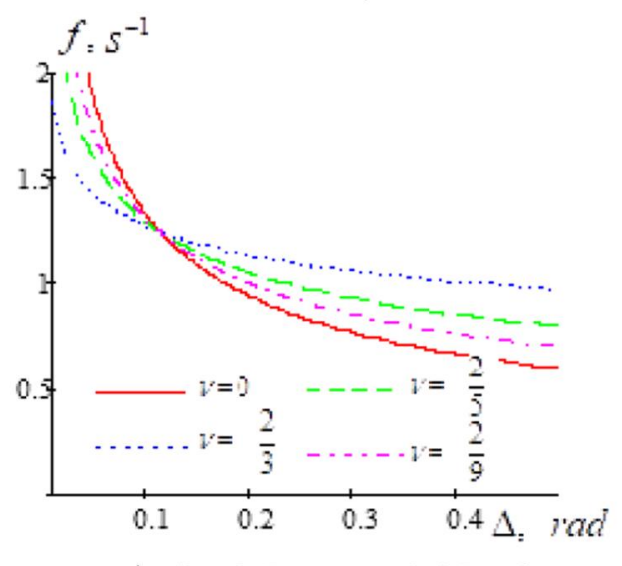

e) $\delta=2.5 \mathrm{~m}, a_{\varphi}=0.05 \mathrm{rad}$
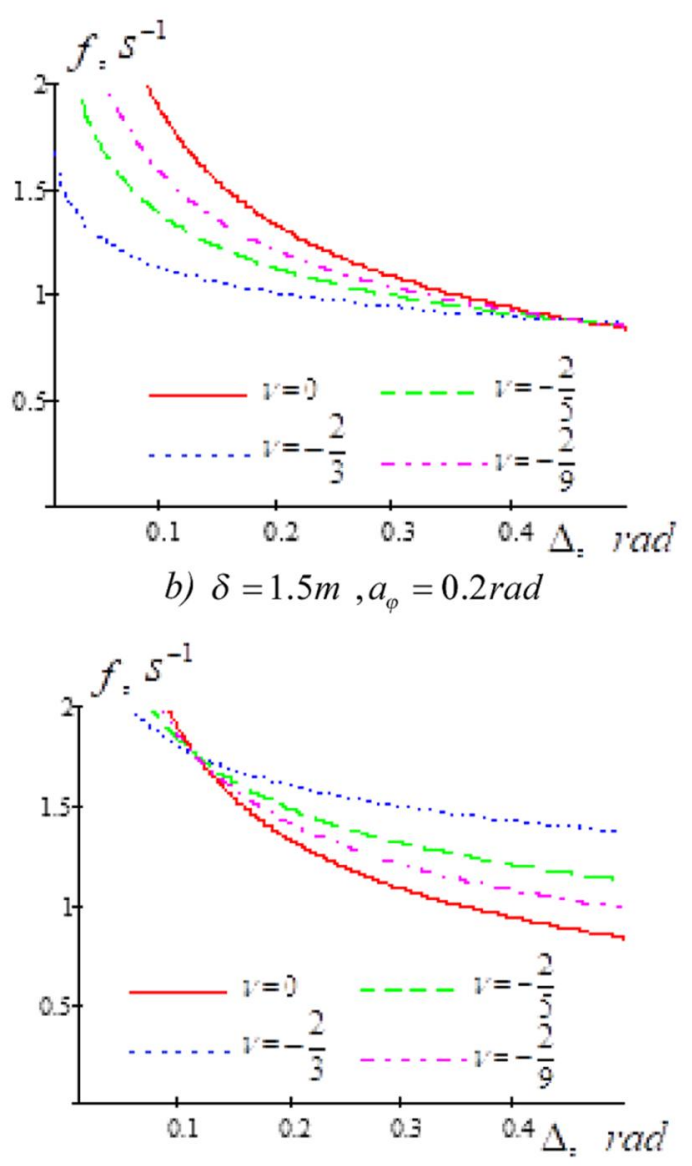

d) $\delta=1.5 m, a_{\varphi}=0.05 \mathrm{rad}$

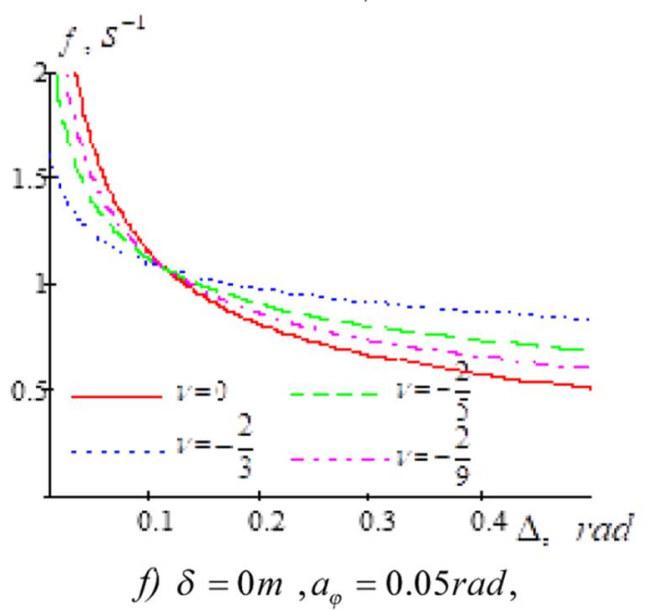

Fig. 4. Dependencies of the frequency of longitudinal-angular oscillations on static deformation at $a=2 \mathrm{~m}, b=3 \mathrm{~m}, c=1,8 \mathrm{~m}, P=10^{5} \mathrm{~N}, Q=4 \times 10^{5} \mathrm{~N}$ 
From the dependencies presented in Fig. 4, it follows that:

1. A larger value of static deformation corresponds to a smaller value of the natural frequency of longitudinal-angular oscillations (at constant amplitude);

2. The speed of decrease of the natural frequency with increasing static deformation for the progressive law of change of elastic force for small values of static deformation is greater than for the suspension with the classical linear law and smaller - for large values of static deformation of the suspension;

3. For the regression law of change of elastic force, the speed of decrease of the natural frequency for really existing static deformations of suspension systems is greater than for the linear one;

4. Ergonomic conditions of transportation of people without additional amortization for large amplitudes of longitudinal-angular oscillations are more satisfied by a suspension with the progressive law of change of elastic forces and for small amplitudes - with the regressive one.

As for the influence of the resistance forces of shock absorbers, they, as noted above, cause attenuation of the amplitude of oscillations. Without going into mathematical calculations for the specified type of the law of change of force of resistance of shock-absorbers, the law of its change is defined [8] by a ratio:

$$
\frac{d a_{\phi}}{d t}=-\frac{\left(\alpha_{1}(a+\delta)^{s+2}+\alpha_{2}(b-\delta)^{s+2}\right) a}{2 \Pi I_{0}}\left(\frac{2 a \omega\left(a_{\phi}\right)}{(v+2)}\right)^{s-1} \Gamma\left(\frac{1}{v+2}\right) \Gamma\left(\frac{s+2}{2}\right) \Gamma^{-1}\left(\frac{1}{v+2}+\frac{s+2}{2}\right) .
$$

Fig. 5 shows the change in time of amplitudes and frequencies of longitudinal-angular oscillations according to equation (9).

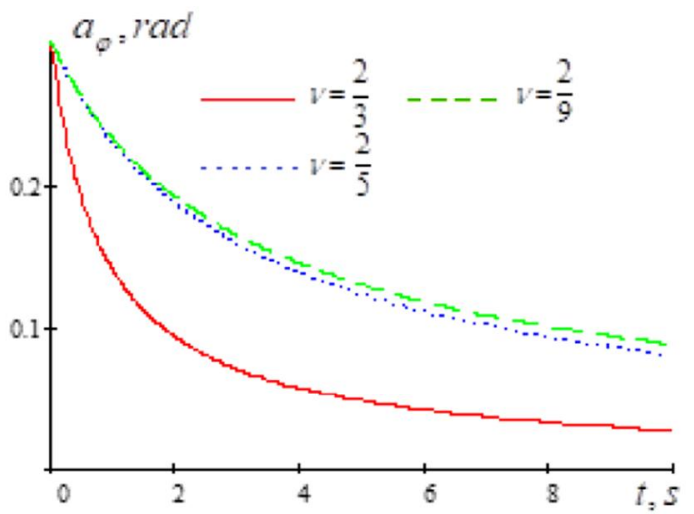

a) $\delta=2 m, \Delta=0.3 m$

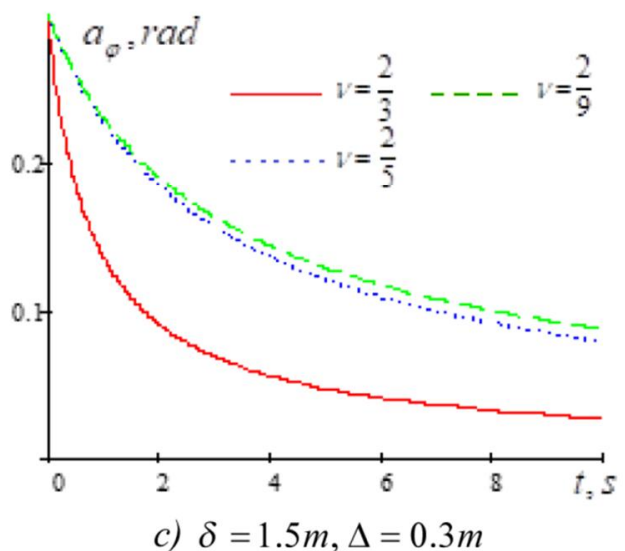

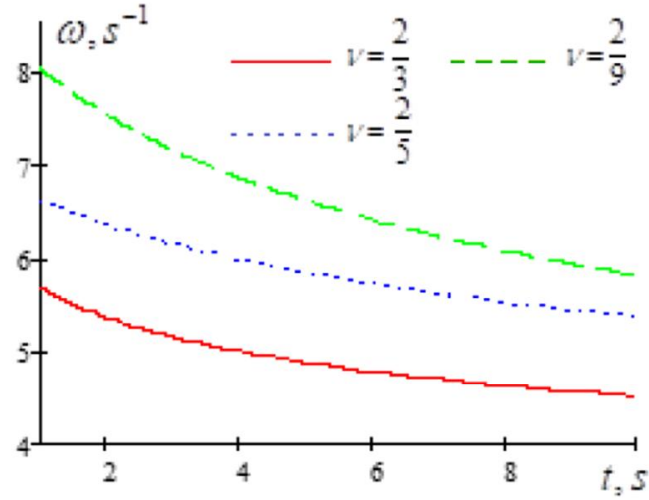

b) $\delta=2 m, \Delta=0.3 m$

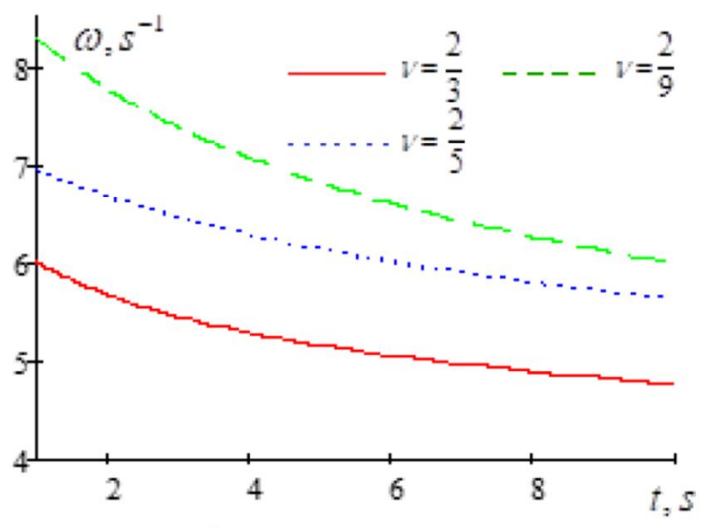

d) $\delta=1.5 \mathrm{~m}, \Delta=0.3 \mathrm{~m}$

Fig. 5. Change in time of the amplitude-frequency characteristic at different parameters of the suspension and the location of the load 


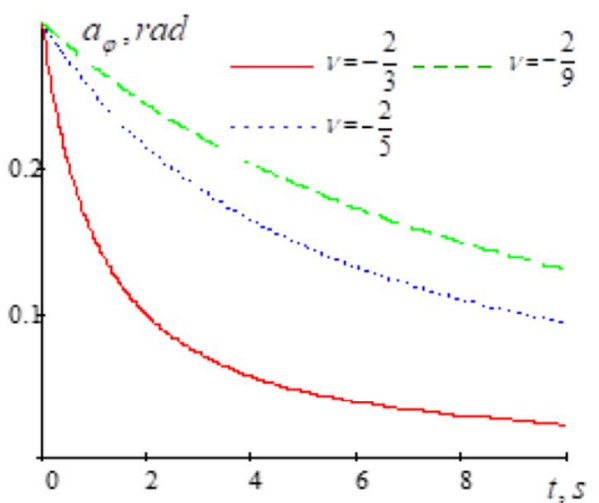

e) $\delta=1.5 m \quad \Delta=0.2 m$

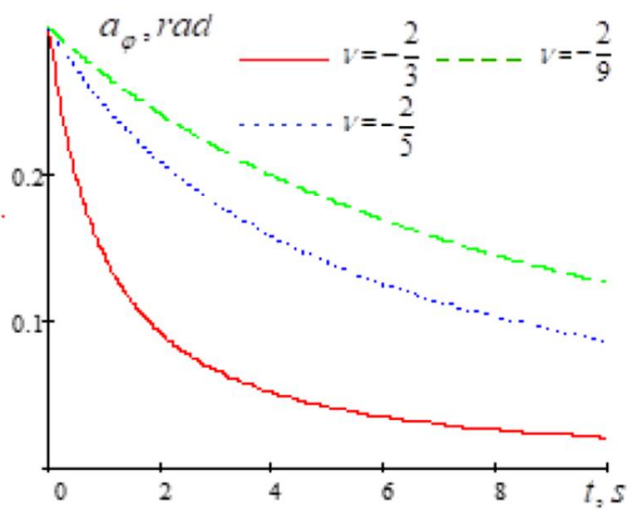

g) $\delta=1.5 \mathrm{~m}, \Delta=0.15 \mathrm{~m}$

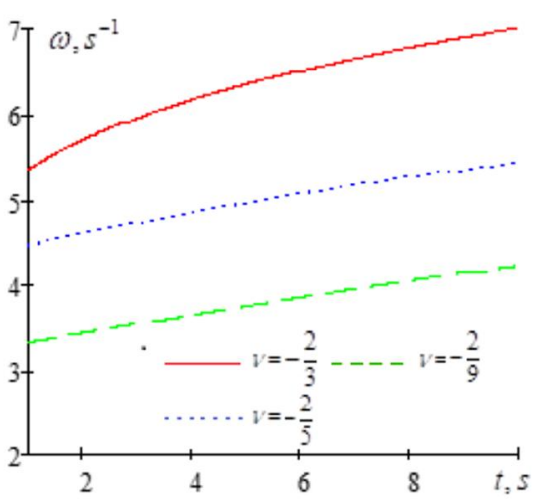

f) $\delta=1.5 m, \Delta=0.2 m$

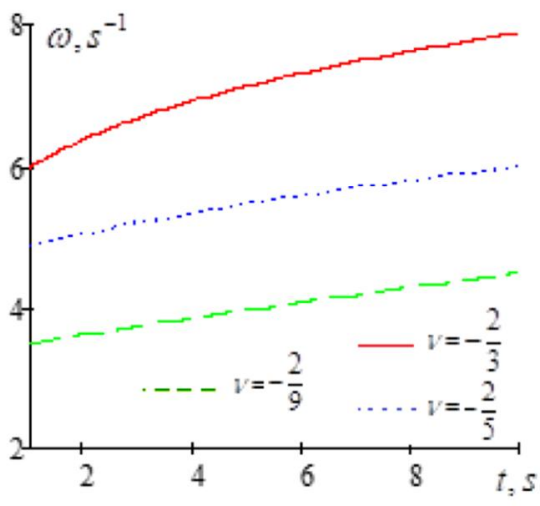

h) $\delta=1.5 \mathrm{~m}, \Delta=0.15 \mathrm{~m}$

Fig. 5. (Continuation). Change in time of the amplitude-frequency characteristic at different parameters of the suspension and the location of the load

The graphical dependencies presented in Fig. 5 show that the rate of decrease of the amplitude of longitudinal-angular oscillations for the suspension system with the progressive or regressive law of change of elastic force is greater for larger $v$ and smaller values of static deformation.

Fundamentally different results for the change in time of the frequency of natural oscillations: if for the linear law of change of elastic force for the first approximation it is constant, then for the progressive law of change of elastic force it decreases with time, and for the regressive one - it increases. In addition, the suspension system with the progressive law of change of elastic force with static deformation of the shock absorbers $\Delta \approx 0.3 \mathrm{~m}$ and the closer location of the load that is transported to the rear side satisfies the ergonomic conditions for a wide range of time changes to a greater extent.

\subsection{Determination of the dynamic pressure force of steered wheels on the road surface.}

The kinematic relations obtained above, which describe the dynamics of the relative motion of the sprung part of a considered wheeled vehicle, together serve the main relations arising from the kinetostatics equations of the sprung-unsprung part system to determine the dynamic interaction of tires with the road surface and hence the dynamic angle of steerability. For the considered calculation model of a wheeled vehicle with a load, the basic ratio which follows from the equations of kinetostatics of statics is transformed into:

$$
\begin{aligned}
& \vec{R}^{e . a .}+\vec{R}+\vec{\Phi}^{\mathrm{e}}+\vec{\Phi}^{\mathrm{i}}=0, \\
& \vec{M}_{B}\left(\vec{R}^{e . a .}\right)+\vec{M}_{B}(\vec{R})+\vec{M}_{B}\left(\vec{\Phi}^{\mathrm{e}}\right)+\vec{M}_{B}\left(\vec{\Phi}^{\mathrm{i}}\right)=0,
\end{aligned}
$$

where, respectively $\vec{R}^{\text {e.a. }}, \vec{R}^{i}, \vec{\Phi}^{\mathrm{e}}, \vec{\Phi}^{\mathrm{i}}$ - the main vectors of external active forces, reactions of ligaments, transfer and relative forces of inertia, $\vec{M}_{A}\left(\vec{R}^{\text {e.a. }}\right), \vec{M}_{A}(\vec{R}), \vec{M}_{A}\left(\vec{\Phi}^{\mathrm{e}}\right), \vec{M}_{A}\left(\vec{\Phi}^{\mathrm{i}}\right)-$ the main points of these 
forces relative to the arbitrary point B. Let us note that for the considered transfer motion of a wheeled vehicle (translational) the main vector of the Coriolis force of inertia and therefore the main moment of this force relative to the arbitrary point is equal to zero. We would like to note that point B is chosen so that the scalar equations derived from (10) take the simplest form. In our case, these are the contact points of the steered wheels of a vehicle. Thus, from the vector relation (10) for the plane model of the motion of a wheeled vehicle the scalar follows

$$
\begin{aligned}
& -\mathrm{P}_{1 .}-P_{2}-P-Q+N_{1}+N_{2}=0, \\
& F_{p}-F_{1 m p .}-\Phi^{e . H .}-\Phi^{e . n .}-\Phi^{e . \text { в. }}=0, \\
& N_{2}(a+b)-P(a+\delta \cos \phi)-Q(l+a-\delta \cos \phi)-\Phi^{e . H .} r- \\
& -\Phi^{e . \Pi .}(d+\delta \sin \phi)-\Phi^{e . \text { в. }}(l-\delta \sin \phi)-M_{A}^{\mathrm{r} . \Phi}=0,
\end{aligned}
$$

where $N_{1}, N_{2}$ - respectively, are the vertical components of the reactions of the road surface of the steered and driven wheels (equal in magnitude to the pressure forces of the respective wheels on the road surface), $F_{2}, F_{1 m p}$ - driving and resistance force, $F_{1 m p}$ - according to Coulomb's law is related to the dynamic pressure force $F_{1 m p .}=f_{\mathrm{Tp}} N_{1}, \Phi^{\text {e.t. }}=\frac{P_{1}+P_{2}}{\mathrm{~g}} w, \Phi^{\text {e.n. }}=\frac{Q}{\mathrm{~g}} w$ respectively, are the main vectors of inertia forces of non-sprung, sprung parts and the load transported in portable motion, $M_{A}\left(\vec{\Phi}^{\mathrm{i}}\right)=I_{A} \ddot{\phi}-$ the main moment of inertia of relative motion of the sprung mass with the load relative to the point of contact (adherent point) of the steered wheel and the road surface (point A), $r$ - a wheel radius.

From the system of differential equations (11), we can find without special difficulties $F_{p}=f_{\text {тр }} N_{1} \pm \frac{w}{g}\left(P+P_{\text {н }}+Q\right)$. In addition, based on the dependence (1), the third equation of relations (11) can be somewhat simplified by presenting it as follows:

$$
N_{2}(a+b)-\frac{P+Q}{g}(g(a+\delta) \pm h w) \mp I_{A} \ddot{\phi} \mp \frac{P_{1}+P_{2}}{\mathrm{~g}} w r=0,
$$

where $I_{A}$ is located according to the Huygens-Steiner theorem.

To determine the limit angle of steerability of a vehicle, let's limit to the maximum value of the angular acceleration of the relative motion of the sprung part. From the obtained relation (6) we can get the following:

$$
\left\{\begin{array}{l}
\max \\
\min
\end{array}\right\} \ddot{\phi}(t)= \pm \frac{a_{\phi}^{v+1}}{I_{0}}\left(c_{1}(a+\delta)^{v+2}+c_{2}(b-\delta)^{v+2}\right) .
$$

Thus, the extreme values of the pressure force of the leading wheel on the road surface are equal

$$
N_{2}=\frac{1}{(a+b)}\left\{\frac{P+Q}{g}(g((a+\delta)) \pm h w) \pm \frac{I_{A}}{I_{O}} c_{1}\left[(a+\delta)^{v+2}+\kappa(b-\delta)^{v+2}\right] a_{\phi}^{v+1} \mp \frac{P_{1}+P_{2}}{\mathrm{~g}} w r\right\} \text {. }
$$

The upper sign in the above dependencies is taken for the accelerated motion and the lower - for the slow one. According to the first equation of dependencies (11), we have extreme values of the pressure force of the steered wheel on the support surface

$$
\begin{gathered}
G_{k}=N_{1}=\mathrm{P}_{1 .}+P_{2}+P+Q- \\
-\frac{1}{(a+b)}\left\{\frac{P+Q}{g}(g(a+\delta) \pm h w) \pm \frac{I_{A}(P+Q)}{I_{O}(1+\kappa)}\left[(a+\delta)^{v+2}+\kappa(b-\delta)^{v+2}\right] \frac{a_{\phi}^{v+1}}{\Delta_{\mathrm{cT} .}^{v+1}} \mp \frac{P_{1}+P_{2}}{\mathrm{~g}} w r\right\} .
\end{gathered}
$$




\subsection{Limit angle of steerability.}

The dependence (15) is the basis for determining the dynamic angular stiffness (similar to static) of the tire $c_{\omega}$ relative to the vertical axis $c_{\omega}=k G_{k}$, the coefficient $k$ is determined by empirical dependence. At the same time, the moment of dynamic resistance of the tire rotation, provided that the latter is proportional to the angle of rotation of the tire [1], takes the following form:

$$
\begin{gathered}
M_{\phi}=k\left\{\mathrm{P}_{1 .}+P_{2 .}+P+Q-\frac{1}{(a+b)}\left\{\frac{P+Q}{g}(g(a+\delta) \pm h w) \pm\right.\right. \\
\left.\left. \pm \frac{I_{A}(P+Q)}{I_{O}(1+\kappa)}\left[(a+\delta)^{v+2}+\kappa(b-\delta)^{v+2}\right] \frac{a_{\phi}^{v+1}}{\Delta_{\mathrm{cT} .}^{v+1}} \mp \frac{P_{1}+P_{2}}{\mathrm{~g}} w r\right\}\right\} \Theta,
\end{gathered}
$$

where $\Theta$ - the angle of rotation of the steered wheel relative to the axis of the pin (the axis relative to which the wheel rotates). The condition of steerability of a wheeled vehicle (taking into account the oscillations of the sprung part and the variable of speed motion $d V / d t=w$ takes the form $M_{\varphi} \leq M_{\varphi \max }$, where $M_{\varphi \max }$ - the limit value of the coupling torque resistance of the tire which occurs when the sliding of the tire elements that are in contact with the supporting surface [1].

The latter can be taken as the maximum value of the static moment of resistance of the tire rotation: $M_{\phi \max }=k\left(P_{1}+(P+Q) a /(a+b)\right) \Theta_{\max }, \Theta_{\max }-$ the limit value of the angle of rotation of the steered wheel, which for different types of the road pavement is found empirically. In this case, to determine the limit angle of rotation of the steered wheel, taking into account the longitudinal oscillations of the sprung mass, we obtain the following dependence:

$$
\begin{gathered}
\left\{\mathrm{P}_{1 .}+P_{2 .}+P+Q-\frac{1}{(a+b)}\left\{\frac{P+Q}{g}(g(a+\delta) \pm h w) \pm \frac{I_{A}(P+Q)}{I_{O}(1+\kappa)}\left[(a+\delta)^{v+2}+\right.\right.\right. \\
\left.\left.\left.+\kappa(b-\delta)^{v+2}\right] \frac{a_{\phi}^{v+1}}{\Delta_{\text {ст. }}^{v+1}} \mp \frac{P_{1}+P_{2}}{\mathrm{~g}} w r\right\}\right\} \Theta\left(P_{1}-\frac{P+Q}{a+b} a\right) \Theta_{\max } .
\end{gathered}
$$

From obtained dependence, we can find the value of critical dynamical angle of rotation $\bar{\Theta}$ depending on the amplitude of longitudinal-angular oscillations, acceleration of the wheeled vehicle, and parameters that describe power characteristic of the sprung mass and the location of the cargo in the body.

$$
\begin{aligned}
\bar{\Theta} & =\left(\left(P+P_{1}\right)(a+b)-P a \pm \frac{P_{1}+P_{2}}{\mathrm{~g}} w r\right) /\left((a+b)\left(\mathrm{P}_{1 .}+P_{2}+P+Q\right)-\left[\frac{P+Q}{g}(g(a+\right.\right. \\
& \left.\left.+\delta) \pm w h) \pm \frac{I_{A}(P+Q)}{I_{O}(1+\kappa)}\left[(a+\delta)^{v+2}+\kappa(b-\delta)^{v+2}\right] \frac{a_{\phi}^{v+1}}{\Delta_{\text {ст. }}^{v+1}} \mp \frac{P_{1}+P_{2}}{\mathrm{~g}} w r\right]\right) \Theta_{\max } .
\end{aligned}
$$

The dependence of the relation of the critical value of dynamical angle of rotation to its static value ( $\left.\eta=\bar{\Theta} / \Theta_{\max }\right)$ at different values of parameters of suspension force and accelerations of wheeled vehicle for progressive and regressive characteristics of the suspension system is given in Fig. 6.

The given graphical dependencies show that longitudinal-angular oscillations significantly reduce the critical value of the dynamic angle of steerability. As for the influence of oscillation amplitude and characteristics of the elastic force of the suspension, its regressive dependence should be chosen for practical use to increase steerability which can increase the dynamic value of the angle of steerability significantly comparred to the linear one for a wide range of longitudinal-angular oscillations. At the same time, the limit value of the dynamic angle of steerability is greater, provided that the transported load is at a greater distance from the rear side. 


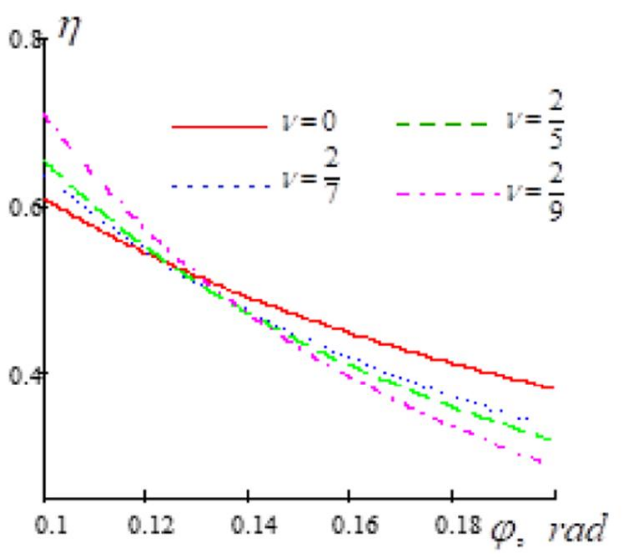

a) $\mathrm{h}=1.5 m, \Delta=0.3 m, w=1 m \cdot s^{-2}$



c) $\mathrm{h}=2 m, \Delta=0.2 m, w=1 m \cdot s^{-2}$

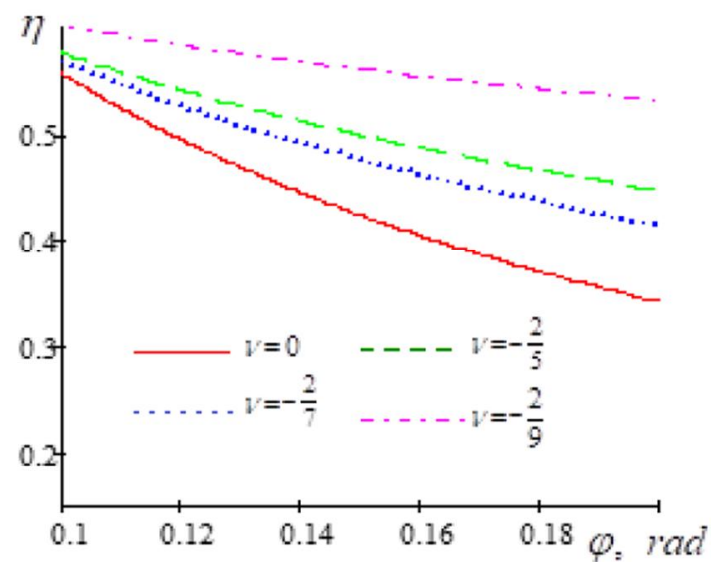

e) $\mathrm{h}=1.8 m, \Delta=0.3 m, w=1 m \cdot s^{-2}$

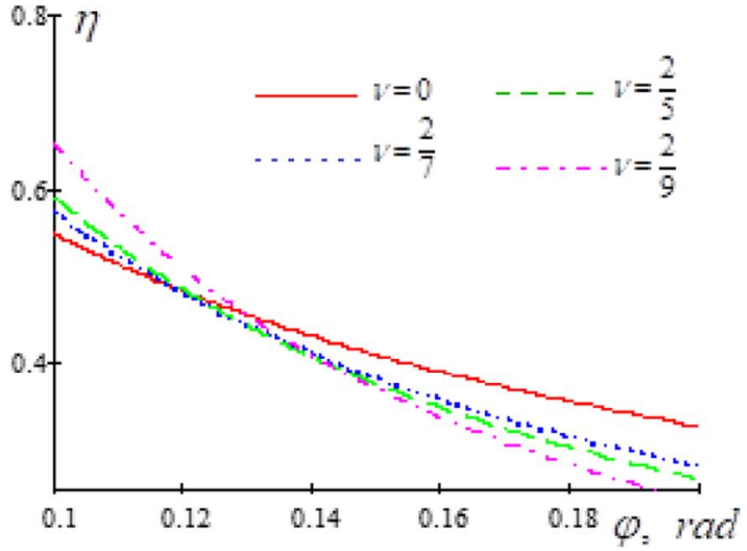

b) $\mathrm{h}=1.5 m, \Delta=0.2 m ! w=1 m \cdot s^{-2}$

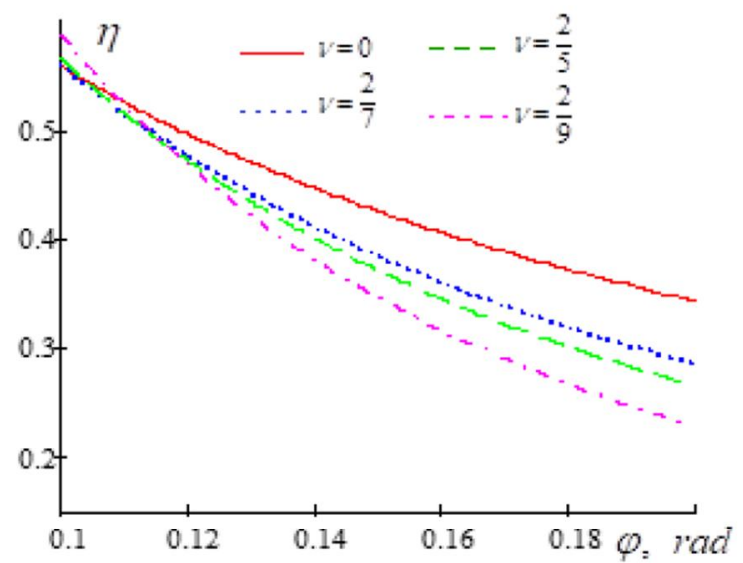

d) $\mathrm{h}=2 m, \Delta=0.3 m, w=1 m \cdot s^{-2}$

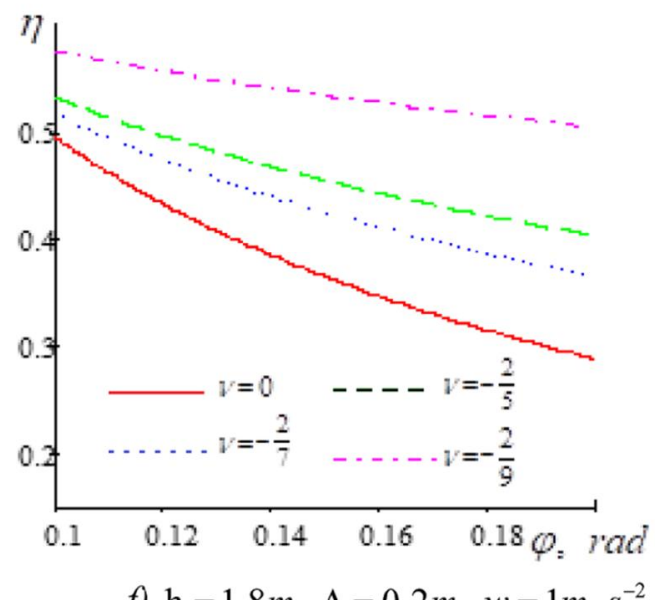

Fig. 6. Dependence of the ratio of the critical value of the dynamic angle of rotation to its static value ( $\eta=\bar{\Theta} / \Theta_{\max }$ ) at different values of the parameters of the suspension force and the location of the load transported at $a=2 m, b=3 m, c=1,8 m$

\section{CONCLUSIONS AND RESEARCH PERSPECTIVES}

The obtained results and the presented graphical dependences show:

- firstly, for wheeled vehicles with the nonlinear law of change of regenerative force of the suspension system, the natural frequency of longitudinal - angular oscillations depends on the amplitude, besides for the suspension system with the progressive law of change of regenerative 
force, the bigger value of amplitude corresponds to the bigger value of the natural frequency of oscillations; for the regressive law - vice versa;

- secondly, longitudinally - angular oscillations of the sprung mass significantly reduce the critical (limit) value of the angle of steerability - for larger values of the amplitude of the specified oscillations, the critical value of the angle of steerability is smaller;

- thirdly, the variable in the time of the speed of the vehicle changes the value of the critical angle of steerability - the accelerated movement (at the same other parameters) corresponds to a larger value of the dynamic angle of steerability and vice versa;

- fourthly, for larger values of static deformation of the suspension system with the progressive law of change of elastic force, the critical value of the dynamic angle of rotation is greater and for the regressive - smaller;

- fifthly, the location of the center of the load which is transported closer to the rear side increases the critical value of the angle of steerability;

- sixthly, for small amplitudes of oscillations of the sprung part, the critical value of the stable motion of the suspension with the progressive law of change of elastic force is less than for the linear law and vice versa.

The use of a mathematical model allowed us to analytically establish the influence of various factors (design parameters) on the smoothness and a fairly accurate description of the oscillations of a vehicle when driving on peculiar road pavement. This methodology of studying the influence of longitudinalangular oscillations of wheeled vehicles with nonlinear force characteristics of the suspension system on their steerability is implemented in articles [21-22].

\section{References}

1. Hu, L., Fang, S., \& Yang, J. (2014). Study of the Vehicle Controllability and Stability Based on Multi-body System Dynamics. The Open Mechanical Engineering Journal, 8(1), 865-871. doi: 10.2174/1874155X01408010865 (in English)

2. Ulsoy, A., Peng, H., \& Çakmakci, M. (2012). Vehicle Stability Control. Automotive Control Systems (pp. 257-271). Cambridge: Cambridge University Press. doi:10.1017/CBO9780511844577.018 (in English)

3. Zhao, W., Qin, X., \& Wang, C. (2018). Yaw and lateral stability control for four-wheel steer-by-wire system. IEEE/ASME transactions on mechatronics, Volume 23 (6), 2628-2637. doi: 10.1109/TMECH.2018.2812220 (in English)

4. Pukach, P. Y., Kuzio, I. V., Nytrebych, Z. M., \& Il'Kiv, V. S. (2018). Asymptotic method for investigating resonant regimes of nonlinear bending vibrations of elastic shaft. Scientific Bulletin of National Mining University, Volume 1, 68-73. doi:10.29202/nvngu/2018-1/9 (in English)

5. Calvo, J. A., San Román, J. L., \& Álvarez-Caldas, C. (2013). Procedure to verify the suspension system on periodical motor vehicle inspection. International journal of vehicle design,63(1), 1-17. doi: 10.1504/IJVD.2013.055497 (in English)

6. Sakhno, V. P., Yashchenko, D. M., Marchuk, R. M., Marchuk, N. M., \& Lyashuk, O. L. (2020). Research of a Truck Train Movement when Driving Semitrailer by Slowdowning of Wheels of One Axis Pin on the Model. International Journal of Automotive and Mechanical Engineering, 17(1), 7749-7757. doi: 10.15282/ijame.17.1.2020.21.0576 (in English)

7. Ahmad, I., \& Khan, A. (2018). A comparative analysis of linear and nonlinear semi-active suspension system. Mehran University Research Journal of Engineering and Technology, Volume 37(2), 233-240. (in English)

8. Hrubel M., Nanivskyy R., \& Sokil M. (2014). Kolyvannya pidresorenoyi chastyny kolisnoho transportnoho zasobu ta yikh vplyv na stiykist rukhu vzdovzh kryvoliniynoyi dilyanky shlyakhu [Oscillations of the sprung part of wheeled vehicles and its influence on road holding along the curvilinear stretch of a track]. Naukovyy visnyk NLTU Ukrayiny [Scientific Bulletin of UNFU], Volume 24.1, 155-162. (in Ukrainian)

9. Georgiev, Z., \& Kunchev, L. (2018). Study of the vibrational behaviour of the components of a car suspension. In MATEC Web of Conferences (Vol. 234, p. 02005). EDP Sciences. doi: 10.1051/matecconf/201823402005 (in English)

10. Hrubel M. Nanivskyi R. \& Sokil M. (2015). Rezonansni kolyvannia pidresorenoi chastyny kolisnykh transportnykh zasobiv pid chas rukhu vzdovzh vporiadkovanoi systemy nerivnostei [Resonant oscillations of the 
sprung part of wheeled vehicles when moving along the ordered system of inequalities], Visnyk Vinnyts $\square$ koho politekhnichnoho instytutu [The journal "Visnyk of Vinnytsia Polytechnical Institute"], Volume 1, 155-161 (in Ukrainian)

11. Bozhkova L. V. Riabov V. H. \& Norytsyna H. Y. (2009). Vlyianye poperechnykh vynuzhdennykh kolebanyi kuzova na oprokydyvanye avtomobylia pry obezde prepiatstvyiaia [Influence of the cross-section forced fkuctuations of a body on car overturning at an obstacle detour], Transportne dilo Rosiyi, [Transport business in russian], Volume 3, 141-151 (in Russian)

12. Andruhiv, A., Sokil, B., Sokil, M., Vovk, Y., \& Levkovych, M. (2019). The influence of the cinematic parameters of movement and sprung mass vibrations of wheeled vehicles on the move along the curvedlinear sections of the way. Materialy Mizhnarodnoi naukovo-tekhnichnoi konferentsii „,Aktualni problemy transportu “ [Proceedings of the International Scientific and Technical Conference "Actual Problems of Transport"], 259-264. (in English)

13. Sokil, B., Lyashuk, O. L., Sokil, M., Popovich, P. V., Vovk, Y. Y., \& Perenchuk, O. Z. (2018). Dynamic Effect of Cushion Part of Wheeled Vehicles on Their Steerability. International Journal of Automotive and Mechanical Engineering, Volume 15, Issue 1, 4880-4892. doi: 10.15282/ijame.15.1.2018.1.0380 (in English)

14. Pavlovskyy M.A., Putyata T.V. (1985). Teoretycheskaya mekhanyka: dlya stud. Vuzov [Theoretical mechanics for university students] Vyshcha shkola. (in Russian)

15. Koul Dzh. (1972). Metody vozmushcheniy v prikladnoy matematike [Compensation methods in applied mechanics]. Mir (in Russian)

16. Senyk P. M. (1969). Obernennya nepovnoyi Veta-funktsiyi [Inversion of an incomplete Veta function]. Ukr. mat. Zhurnal [Ukr. mat. Journal], 21(3), 325-333. (in Ukrainian)

17. Nazarkevych, M. (2012). Doslidzhennya zalezhnostey Beta- ta Ateb-funktsiy [Investigation of dependences of beta and ateb functions]. Kompyuterni nauky ta informatsiyni tekhnolohiyi [Computer science and information technology]. 732, 207-216 (in Ukrainian)

18. Silveira, M., Wahi, P., \& Fernandes, J. C. M. (2017). Effects of asymmetrical damping on a 2 DOF quarter-car model under harmonic excitation. Communications in Nonlinear Science and Numerical Simulation, 43, 14-24. doi: 10.1016/j.cnsns.2016.06.029 (in English)

19. Pavlenko, V. M., \& Kryvoruchko, O. O. (2014). Suchasnyy stan rozvytku aktyvnykh pidvisok dlya lehkovykh avtomobiliv [Modern state of development of active suspensions of motor cars]. Visnyk NTU KhPI [Bulletin NTU KhPI], Automobile and tractor manufacture, 1052, 54-60. (in Ukrainian)

20. Sert, E., \& Boyraz, P. (2017). Optimization of suspension system and sensitivity analysis for improvement of stability in a midsize heavy vehicle. Engineering science and technology, an international journal, 20(3), 9971012. doi: 10.1016/j.jestch.2017.03.007 (in English)

21. Artyushenko, A., \& Suyarkov, O. (2013). Vyvchennia vplyvu kharakterystyk pidvisky malohabarytnoho avtomobilia na yakist yizdy ta yoho modernizatsiia [Study of influence of suspension characteristics of small size car on ride quality and its modernization]. Visnyk NTU KhPI [Bulletin NTU KhPI], 1004, 21-27. (in Ukrainian)

22. Podryhalo, M. A., Volkov, V. P., Boboshko, A. A., Pavlenko, V. A., Baitsur, M. V., Nazarov, A. I., \& Aleksev, V. O. (2006). Стійкість колісних транспортних засобів до заносу при гальмуванні та шляхи його підйому [Wheeled vehicles resistance to skidding whilst breaking and ways of its rising]. Kharkiv: KNARU. (in Ukrainian)

Received 03.02.2021; Accepted in revised form 03.04.2021.

\section{ВПЛИВ СТУПЕНЯ ЗАВАНТАЖЕНОСТІ ТА РОЗМНЩЕННЯ ВАНТАЖУ НА КЕРОВАНІСТЬ ВАНТАЖНИХ ТРАНСПОРТНИХ ЗАСОБІВ}

\footnotetext{
Анотація. Для колісних транспортних засобів з нелінійною силовою характеристикою пружинних амортизаторів та демпферних пристроїв розроблено методику оцінювання впливу ступеня завантаженості, кінематичних параметрів руху на їх керованість вздовж криволінійних ділянок шляху. В основу досліджень покладено рівняння кінетостатики системи підресорена-непідресорена частини та диференціальні рівняння відносного руху
} 
підресореної частини транспортних засобів. Щодо останніх, то вони враховують як завантаженість транспортного засобу, так і нелінійно-пружні характеристики амортизаторів. Для випадку, коли пружні характеристики амортизаторів описуються степеневою або близькою до неї залежністю, вдалось аналітично описати коливання підресореної частини. Їх особливістю є те, що частота, а отже, динамічна сила тиску коліс на опорну поверхню (дорогу) залежить від амплітуди коливань. Остання та характеристики дорожнього покриття визначають основні параметри керованості та стійкості руху транспортних засобів вздовж криволінійних ділянок шляху. Все в сукупності дало змогу отримати залежність критичного значення динамічного кута повороту керованих коліс як функиію амплітуди поздовжньо-кутових коливань, кінематичних параметрів руху, ступеня завантаженості транспортного засобу. В результаті встановлено: а) коливання підресореної частини значною мірою зменшують граничний кут повороту керованих коліс вздовж криволінійних ділянок шляху; б) для періоду розганяння транспортного засобу і ближчого розташування центра ваги вантажу, який транспортується, до заднього борта граничний динамічний кут повороту керованих коліс є меншим; в) система підвіски з прогресивним законом зміни відновлювальної сили пружинних амортизаторів у ширшому діапазоні зміни амплітуди коливань підресореної частини задовольняє ергономічні умови перевезення. Отримані розрахункові залежності можуть бути базовими під час модернізачії наявних чи створення нових систем підресорювання з метою покращення основних експлуатаційних характеристик колісних транспортних засобів.

Ключові слова: транспортні засоби, керованість, стійкість руху, система підресорювання, підресорена частина, критична швидкість руху, коливання, навантаження. 